\title{
Banning of Glyphosate and its Impact on Paddy Cultivation: A study in Ratnapura District in Sri Lanka
}

\author{
S. H. P. Malkanthi ${ }^{1 *}$, U. G. Sandareka ${ }^{1}$, A. W. Wijerathne ${ }^{1}$ and P. Sivashankar ${ }^{1}$ \\ Received: $27^{\text {th }}$ June 2018 / Accepted: 25 th August 2018
}

\begin{abstract}
Purpose: It is high time to study the impacts of banning of glyphosate in paddy (rice) cultivation in the country as it is important in many aspects of the economy. The quantity of glyphosate has been in use far exceeds the total of all other pesticides especially for paddy cultivation. The government banned glyphosate in order to save Sri Lanka's agricultural sector especially farmers from the chronic kidney disease (CKD). This unexpected situation has created problems for farmers. This study was conducted to assess the impacts of banning of glyphosate for paddy cultivation in Ratnapura district.
\end{abstract}

Research Method: Ratnapura district was selected as the research area because paddy cultivation has been conducted in many Divisional Secretarial divisions of it. A Sample of 100 paddy farmers was randomly selected and data was collected using a field survey from June to November in 2017. Descriptive statistics and paired t-tests were used to analyze the data.

Findings: Results revealed that most of the paddy farmers are male farmers and they are at their middle ages. They have a significant level of education. However, most of them have very small size farm lands and their monthly income is very low. Furthermore, majority of them have a good understanding about positive and negative aspects of glyphosate. Moreover, some farmers are spending much on other herbicides due to unavailability of glyphosate. Hence, there is a significant difference in cost spent for herbicides before and after banning glyphosate. While some farmers are moving away from farming, some farmers are turning to use cultural practices.

Originality/Value: Farmers wish to move away from glyphosate if they have a suitable alternative. But at the moment they are facing problems due to unavailability of alternatives for glyphosate. So that, finding for a better alternative for the glyphosate is a felt need.

Keywords: Environmental pollution, glyphosate, herbicides, paddy cultivation, weed management

\section{INTRODUCTION}

Sri Lanka is an agricultural country and the staple food is rice. According to the ancient records, rice cultivation goes back to the period of Anuradhapura kingdom from $377 \mathrm{BC}$ to 1017AD, the first capital of Sri Lanka. As rice production was so much successful during that period, Sri Lanka was known as 'Granary of the East' (Anon, 2009). Currently rice is the single most important food crop occupying 34 percent ( 0.77 million hectares) of the total cultivated area in the country. An average of 560,000 ha are cultivated during Maha season and 310,000 ha during Yala season making the average annual extent sown with rice to about 870,000 ha (Table 01). About 1.8 million farm families' engage in rice cultivation island-wide. Sri Lanka currently produces 2.7 million tons of paddy annually and satisfies around 95 percent of the domestic requirement. Rice provides 45 percent of total calorie and 40 percent of

$I^{*}$ Faculty of Agricultural Sciences, Sabaragamuwa University of Sri Lanka

malkanthi09@gmail.com

ORCID https://orcid.org/0000-0002-2438-9976 
the total protein requirement of an average Sri Lankan (Rice Research and Development Institute, Bathalagoda (RRDI), 2017).

Ancient agriculture mainly depended on organic compounds. Rice cultivation in the country was completely based on indigenous techniques that were based on the experience and knowledge of local farmers that had been verified over thousands of years of application by maintaining sustainability in farming. Farmers have used traditional rice varieties as well as traditional and conventional methods for their cultivation such as organic fertilizer for plant nutrients, 'Kem' method for pest and disease control. They have also used traditional harvesting, processing and storing methods (Irangani and Shiratake, 2013).

However, today farmers engage in modern rice cultivation with the overuse of agro chemicals and inorganic compounds. This has caused to generate negative impacts for farmers and also for the environment. Weed control in rice cultivations is a serious problem. It has to be done at three stages, namely pre planting, pre emergence and post emergence. It is recommended to use herbicides for paddy cultivation in combination with other weed control methods such as cultural, manual and mechanical weed controlling. However, farmers are using extra amount of weedicides for the cultivation in order to control weeds rather than using an integrated weed management method. They use herbicides in the different stages of life cycle of the rice plant, because weeds vary in different places according to the type of rice cultivate, tillage type, soil type and irrigation pattern. According to the RRDI, Bathalagoda there are 134 weed species identified in paddy fields in Sri Lanka. It includes more than 70 species of grasses, about 50 species of sedges and about 20 species of broad leaves. Same as in most of the other countries, glyphosate had been used as the most effective herbicide to control weeds in rice cultivation areas in Sri Lanka too (Ekanayaka et al., 2017).

\section{What is glyphosate?}

Glyphosate is a post-emergent, systemic and non-selective (or broad-spectrum) herbicide used in both agricultural and non-agricultural areas. It was discovered in1970 by John E. Franz (Franz et al. 1997). The molecule includes carboxylic ion and a phosphoric ion in the ends of the molecule. So it has both $\mathrm{H}^{+}$donor and acceptor functional groups (Figure 01) (Darvas, 2012).

It is also considered as a selective herbicide which can kill wide range of weeds without killing the crops. Once absorbed by the plant, glyphosate binds to and blocks the activity of the enzyme enolpyruvylshikimate-3-phosphate synthase (EPSPS). The EPSPS enzyme comes at the start of the shikimic acid pathway that converts simple carbohydrate precursors derived from glycolysis and the pentose phosphate pathway to aromatic amino acids and many other important plant metabolites. The enzyme is normally located within the chloroplasts where it catalyses the reaction of shikimate3-phosphate (S3P) and phosphoenol pyruvate to form 5-enolpyruvyl-shikimate-3-phosphate (ESP). ESP is a precursor for aromatic amino acids and, ultimately, hormones, vitamins and other essential plant metabolites. Structural similarities to phosphoenol pyruvate enable glyphosate to bind to the substrate binding site of the EPSPS, inhibiting its activity and blocking its import into the chloroplast. Since the active site of the EPSPS enzyme is highly consistent in higher plants, glyphosate affects a broad spectrum of weeds indiscriminately. Inhibiting the function of the shikimic acid pathway causes a deficiency in aromatic amino acids, eventually leading to the plant's death by starvation (Duke and Powles, 2008; Sirinathsinghji, 2012). When glyphosate was introduced to the market in 1976, it said that the glyphosate will cause minimum toxicity to mammals, fish, insects and bacteria and has low impact on vegetation (Giesy et al., 2000). 


\section{Table 01: Two rice cultivation seasons in Sri Lanka}

\begin{tabular}{ccccc}
\hline Season & Planting & Harvesting & Percentage & Dependent Monsoon \\
\hline Yala & April - May & August -September & $30 \%$ rice production & Southwest \\
Maha & October - November & February - March & $70 \%$ rice production & Northeast \\
\hline
\end{tabular}

Source: (RRDI, 2017)<smiles>O=C(O)CNCP(=O)(O)O</smiles>

Figure 01: Chemical formula of glyphosate molecule

Glyphosate is strongly absorbed to the soil. Thus, there is a negligible threat of residual effects on succeeding rotational crops (Madsen and Streibig, 2000). Subsequent microbial degradation may prevail many months in soils with low microbial activity (Sprankle et al., 1975). Glyphosate absorption can be inhibited by adding of phosphorous to the soil (Hance, 1976). Wood bio char is a potential soil amendment to reduce glyphosate leaching in agricultural soils. Despite being the most widely used herbicide in the world, in 2015 glyphosate was classified as 'probably carcinogenic to humans' by the International Agency for Research on Cancer (World Health Organization, 2015).

\section{Advantages of glyphosate}

Comparatively there are numbers of positive aspects of glyphosate. Glyphosate typically kills weeds within two to ten days, thereby helping to increase yields and productivity. It may also save time and effort compared to traditional hand or mechanical weeding. As an added benefit, glyphosate can quickly eliminate weeds and other unwanted vegetation while leaving the glyphosate-resistant plants safe and healthy.

As glyphosate has a charged phosphate group binds strongly to soil, water pollution is very low. Glyphosate is degraded to amino methyl prosphonic acid (AMPA) and carbon dioxide by soil microbes. Glyphosate and its degraded product AMPA are considered to be much less toxic than herbicides that were used prior to it (Mathew, 2017).

Glyphosate gets absorbed by the particles immediately than other herbicides and starts to break down into natural, nontoxic substances, meaning it has a very low rate of persistence. Compared to many other kinds of herbicides, pure glyphosate is very low in toxicity to human beings. This may make it much safer than other chemicals which may be tempted to use in gardens and lowers the risks of health problems related to herbicide exposure.

Another problem with some other herbicides is running off into waterways where herbicides may injure fish and other wildlife. Not so with glyphosate when this herbicide is used correctly. The Wisconsin Department of Natural Resources reports that glyphosate is toxic to fish "only at dosages well above the label application rates" (Buffin, and Jewell, 2001). So, it is clear that when compared with other herbicides glyphosate has a strong sorption characteristics by minimizing the risk can occur by leaching.

\section{Disadvantages of use of glyphosate}

Not only advantages, a number of disadvantages are also associated with the use of glyphosate. While glyphosate may be comparatively low in toxicity when judged next to other herbicides, it is still toxic. Exposure to glyphosate can cause skin irritations, difficulty in swallowing, 
diarrhea and vomiting warns the National Pesticide Information Center. Glyphosate works by inhibiting the plant's ability to use certain enzyme pathways in the plant's biological structure. This may be applied to all plants unless they have been bred and engineered to resist glyphosate. Thus, while glyphosate controls weeds, it will also effectively kill all other plants in farm lands. As glyphosate causes to deteriorate the plant defense system, the plant pathogens will be increased. This will lead to reduce the plant biomass in the environment.

Glyphosate may be low in persistence. Also persistence cannot be accurately predicted. Everything from the soil temperature and soil $\mathrm{pH}$ levels to general weather can raise or lower glyphosate's persistence rate (Buffin and Jewell, 2001). It is said that when glyphosate is repeatedly applied to the soil it will cause resistance microbial communities which will adapted to the repeated glyphosate application (Lane, 2012). It is said that glyphosate has been causing toxicity to microalgae and other aquatic microorganisms in water (Ma et al., 2003). Not only for microorganisms but also for aquatic life such as Nil tilapia (Jiraungkoorskul et al., 2003), Silver catfish (Glusczak et al., 2007) and Neotropical fish (Prochilodus lineatus) (Langiano et al., 2008).

Glyphosate can link to birth defects. In Argentina in April, 2010, severe birth defects have been documented in babies whose mothers were exposed to glyphosate during pregnancy (Ananda, 2011). In recent years it has been observed that there is a significant increase in chronic kidney disease in some parts of Sri Lanka mainly in North central and North western provinces. Researchers found a link between fatal chronic kidney disease and the paddy farmers who use glyphosate (Copping, 2014).

It is said that overuse of glyphosate will cause adverse effects for the plant growth and it will also cause to reduce the yield (Ekanayaka et al., 2017). So with the research studies it is said that glyphosate causes a serious threat to human health, aquatic ecosystems, livestock and environment (Sirinathsinghji, 2012). However, glyphosate is used in many countries in the world for the control of weeds in a large number of crops including rice, tea, cotton, corn, soybean etc.

\section{Use of glyphosate in the world}

Glyphosate is a widely-used herbicide, also known by the trade name Roundup (Statista, 2018) and it has been used worldwide from 1994 to 2014 according to the reports and evidence. In 1994, about 56.3 million kilograms of glyphosate were used worldwide. By 2014, 825.8 million kilograms of glyphosate were used globally. Over 160 countries worldwide accept the safe use of glyphosate that is supported by one of the most extensive human health; crop residues and environmental database ever complied on a pesticide product. The overwhelming conclusion of experts worldwide is that glyphosate, when used according to label directions, does not present an unreasonable risk of adverse effects to human, wildlife or the environment (Monsanto, 2017). However, European Union (EU) countries have voted to renew the license of glyphosate, at the centre of environmental concerns. EU Commission has announced that the new five-year license will be ready before the current one expires on $15^{\text {th }}$ December. However, France plans to ban the use of glyphosate within three years and had advised to sell glyphosate from locked cabinets in 2015. However, they are going to ban it "as soon as alternatives are found, and within three years at the latest" (EU Commission, 2017).

From 1974-2014, a total of 1.37 billion $\mathrm{kg}$ of glyphosate were applied in the U.S. agricultural sector (Benbrook, 2016). Agricultural uses of glyphosate accounted for $80 \%$ of total national use in USA in 2000. In September 2013, El Salvador bans 53 agrochemicals, including glyphosate. In April 2014, Netherland prohibited the sale of glyphosate to individuals for household use. In May 2015, Bermuda blocked the imports of new orders of glyphosatebased herbicides temporary till the research 
outcome comes. Colombia stopped the usage of glyphosate by October 2015 for the purpose of destructing the illegal plantations of coca. French ecology minister asked nurseries and garden centers to sell glyphosate only from locked cabinets In June 2015. Colombia, the world's largest cocaine producer, suspended in 2015 its use of glyphosate for aerial spraying of illicit crops on concerns it may be carcinogenic. However, it is still used in manual fumigation and authorities are pushing for a return to aerial spraying. Most notable is the London Borough of Hammersmith and Fulham which halted the standardized spraying in public spaces with glyphosate in June 2016. And also Edinburgh, Brighton and Cornwall are among other areas looking at phasing it out. Eight out of ten provinces in Canada also have some form of restriction on the use of glyphosate. Certain retail stores in Germany also have removed glyphosate based herbicides from selves.

In Britain the government, with the backing of the National Farmers' Union, supports the continued use of glyphosate but a number of local authorities have limited its use. California became the first US state to issue a warning on glyphosate by adding it to a list of chemicals known to cause cancer in July 2017. This will not result in a state-wide ban but requires companies selling the product to flag warnings. Some US cities have banned its use in parks. There are also limits in several European countries such as Italy because in 2016, they ended the use of glyphosate in public areas such as parks and football grounds. The Dutch government in March 2016 stopped the use of products containing glyphosate on surfaces and roads, and in France it has been banned to use in public spaces since January 2016.

\section{Use of glyphosate in Sri Lanka}

Sri Lanka started to use glyphosate in 1990's. Initially it was largely used in tea estates and then used for most of the food crops such as soya bean, maize, corn, rice etc. Various vendors in the country imported very large quantities of glyphosate until recent time (Lankaweb, 2018). Glyphosate started to be used by some paddy farmers as a pre plant spray applied 10-14 days before ploughing their fields because it hastened the decomposition of weeds. However, its use by paddy farmers became popular only after the banning of the much cheaper herbicide Paraquat in 2010. Paddy farmers who choose to apply glyphosate prior to ploughing their fields, do so only once every six months (Mulleriyawa, 2015). National Academy of Sciences of Sri Lanka (NASSL) President Vijaya Kumar announced that very limited information is available on glyphosate in Sri Lanka and it does not show the level of glyphosate in drinking water in CKD affected areas (North Central Province of the country) is above the international standards set for safety. Furthermore, CKD is rarely reported from areas such as Ampara, Puttalam and Jaffna or even the wet zone, where glyphosate is used to similar extent".

But, in May 2015 Sri Lanka banned importing of glyphosate for commercial use. The epidemic situation of CKD in North Central province and the findings which show, a connection between the disease and the over use of glyphosate provide the reason for banning of it. However, this banning has created a number of impacts for paddy farmers with their cultivations. Meanwhile, again there was a demand from some group of farmers that "Sri Lanka should immediately lift its ill-conceived ban gazetted in October 2015, if it is to save its agriculture. Sadly, it is only the tea industry that had been agitating for lifting of the ban. Farmers in the dry zone have been misinformed that glyphosate is a cause for the CKD and making them to suffer the economic consequences" (Waidyanatha, 2017). In this context, this research was conducted to study the impacts of banning glyphosate for rice farmers in the country.

\section{Background and justification}

Farmers are suffering from unavailability of a proper weedicide for the use of their farm lands after the banning of glyphosate from May 2015. On the other hand, some scientists suggest that glyphosate may cause serious health issues for human, livestock and aquatic life. If we consider about human health, glyphosate may 
cause to occur brain damages, autism and it can also cause to reduce semen quality (Samsel and Seneff, 2015). Major issue concerned with glyphosate is spreading of CKD especially in North Central province in the country.

As paddy requires higher amount of weedicides to use it in different stages of cultivation, after the banning, lands are overgrown of weeds without having a suitable alternative for effective weed management in paddy cultivation. In the Low country, the banning of glyphosate has also negatively affected the production of coconut, rubber and field crops. Banning of glyphosate has been done without giving an alternative; equally safe and cost effective weed control method. Some farmers explain that cost of production is increasing after banning and this is making farmers to give up farming and move to other jobs. The situation can also be observed among Low country paddy farmers. Therefore, it is important to find out the impacts of banning glyphosate and suitable remedies to overcome this problem in order to support the paddy farmers in their livelihood.

\section{Research problem}

The quantity of glyphosate used far exceeds the total of all other pesticides especially for paddy cultivation. The present government banned glyphosate, and had initially decided to stop using it for paddy cultivation, in order to save Sri Lanka's agricultural sector especially farmers from the CKD that is widespread in the North Central Province in the country. This makes farmers to face an unexpected situation regarding their cultivations with the weed control methods. Under this situation it is important to find out the problems faced by the farmers due to banning of glyphosate for the paddy cultivation in Ratnapura district of the country.

\section{Research questions}

What are the socio-economic factors of paddy in the use of glyphosate by farmers?

What is the cost for weedicide for paddy before and after the banning glyphosate?
What are the farmers' levels of awareness about glyphosate and impact of using it?

What is the farmers' attitude on glyphosate and banning of glyphosate?

What are the alternatives for glyphosate currently used by farmers?

\section{Research objectives}

The objective of this research was to determine the impacts of banning glyphosate for the paddy farmers through identification of the socioeconomic factors of farmers using glyphosate, comparing the cost spend for weedicide and the total cost of production before and after the banning of glyphosate, evaluating the farmers' levels of awareness about the impact of use of glyphosate, determining the farmers' attitude on glyphosate and banning of glyphosate and finally finding out possible alternatives for glyphosate currently used by the farmers.

\section{RESEARCH METHOD}

Ratnapura district (Figure 02) was selected as the research area, as paddy cultivation has been conducted in many Divisional Secretarial (DS) divisions of it. Both small and medium scale paddy fields are there. Farmers use agro chemicals in their farming activities. Ratnapura district consists of 17 Divisional Secretariats (DS) divisions and 575 Grama Niladhari (GN) divisions. While total cultivated paddy land extent is about 16,118 ha and about 1.8 million farm families are engaged in paddy cultivation island-wide (Department of Census and Statistics, 2016), paddy farming population in Ratnapura district is 0.127 million (Ratnapura District Secretariat, 2016). A sample of 100 farmers was selected using multistage random sampling technique for the study. Firstly, two Divisional Secretary's divisions (Imbulpe and Opanayaka) were randomly selected. Then after getting lists of paddy farmers, 50 farmers for each division were randomly selected. Finally 100 farmers were selected for the study. 

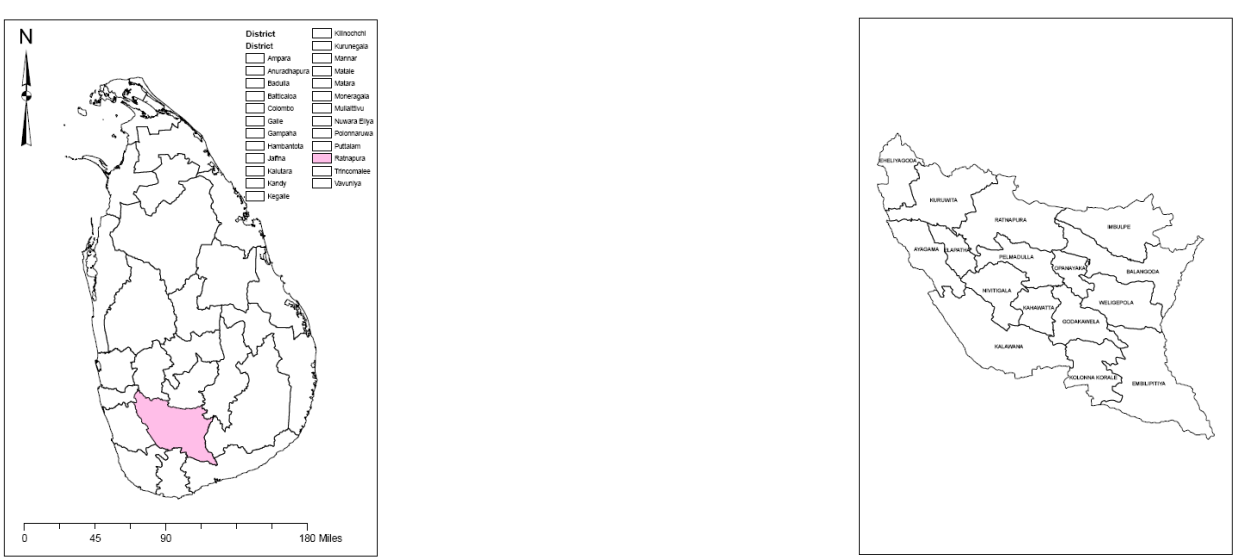

Figure 02: $\quad$ Sri Lanka map showing Ratnapura district

Source: Department of Census and Statistics, 2016

\section{Conceptual framework}

Figure 03 represents the conceptual framework of the study. As per the conceptual framework, banning of glyphosate has created several impacts for the rice farmers such as changes in cost spent for herbicides, paddy production (yield) finding alternatives for glyphosate etc. Moreover, farmers' socio-economic factors, awareness on glyphosate and attitude of the farmers can also affect the impact of the banning of glyphosate.

Primary data were obtained from the farmers using a researcher administered questionnaire survey. The questionnaire has four sections in order to find socio-economic factors, awareness level, farmers' attitudes and alternatives that are used at present. Closed ended and open ended questions were included in the questionnaire and it was pre-tested before the use. Data was collected from June to November in 2017. Secondary data and information were obtained from the Department of Agriculture, Registrar of Pesticides and the Department of Census and Statistics.

\section{Research hypothesis}

There were two sets of hypotheses. First one was used to compare the cost spend for herbicide before and after banning of glyphosate.

H0: There is no significant difference in cost spend for herbicide before and after the banning.

H1: There is a significant difference in cost spend for herbicide before and after the banning.

The other one was used to compare the total cost of production in paddy cultivation before and after the banning of glyphosate.

H0: There is no significant difference in total cost of production in paddy cultivation before and after the banning

H0: There is a significant difference in total cost of production in paddy cultivation before and after the banning

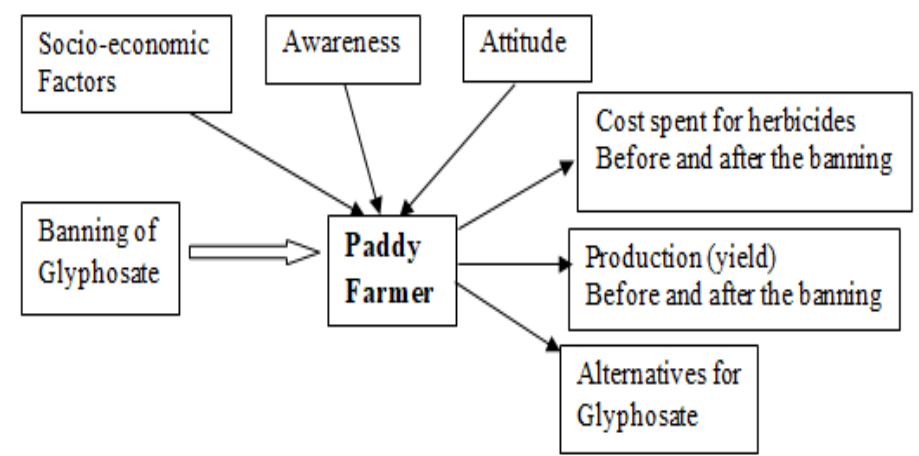

Figure 03: Conceptual framework of the study 
Data was analyzed using descriptive statistics to identify the socio-economic factors of farmers using glyphosate, to evaluate the awareness of farmers about the impact of glyphosate. Also, Paired t-test was used to calculate the amount of cost spent for herbicides and the total cost of production before and after the banning of glyphosate. Data was analyzed by using SPSS version 10.0 software package.

\section{RESULTS AND DISCUSSION}

Results of this study are presented in four parts. First part presents the information on socioeconomic factors and the part two explains the awareness levels of the farmers about glyphosate and its impacts and sources of getting knowledge on glyphosate. While third part explains the attitude of the farmers towards glyphosate and banning of glyphosate, last part presents information on the alternatives used by the farmers.

\section{Socio-economic factors of the farmers}

To obtain some background information of farmers, a descriptive analysis was used. Therefore, the most important socio-economic characteristics of farmers were analyzed and the results were presented in the Table 02 .

As shown in the Table 02, out of the respondents, most of them (79\%) were male farmers. Since it is a hard work, in Sri Lanka, mostly male party engages in paddy cultivation. However, females also give lots of supports in many ways. While majority of the farmers $(36 \%)$ belonged to the age category of $46-55$ years another $35 \%$ belong to 56-65 categories. As young people are moving out of paddy farming, mainly old rural people remain in paddy cultivation. With the decreasing farm labour availability, it seems that the number of farm households using glyphosate is increasing over the years. This was also reported by Yeshey and Bajgai (2014) in their study conducted in Bhutan. In focusing marital status, most of them $(86 \%)$ were married. As far as education is concerned, most of the respondents (42\%) have studied up to $\mathrm{O} / \mathrm{L}$ while another significant amount $(23 \%)$ has studied up to A/L. People have a good level of education as there is a good public education system in the country even in rural areas. With regard to family size most of them belongs to the family size of 3-5 category. As same as in most of the countries in the world, the family size of Sri Lanka is gradually reducing. At present, average family size is 4 (Department of Census and statistics, 2016). Different farmers have different size of farm lands. However, most of them $(36 \%)$ have lands in between $1 / 4-1 / 2$ Acre, whereas 31\% have lower than $1 / 4$ Acre lands. As Sri Lanka is a small country comparatively a large number of population, per capita land availability is very low. Furthermore, size of farm lands is also very small. In focusing the monthly income of the respondents, while most of them (38\%) were receiving in between $25,000-50,000 \mathrm{LKR}$, another $31 \%$ of them were receiving $<25,000 \mathrm{LKR}$ per month. Farmers are getting a very low amount of monthly income. It is not sufficient to meet even their basic needs.

Situations of other countries are more or less similar. For instance, majority of the farmers are male in some other Asian countries. In Malaysia and India, more than half of the farmers were over 50 years of age. This is similar to Sri Lankan situation. But illiterate farmers' percentage in India is higher than Sri Lanka and Malaysia (Alam et al., 2010: Samarpitha et al., 2016). Similar to Sri Lanka, in Malaysia, majority of farm families consists with 4-6 family members and in Thailand majority of farm families have 4-5 members (Cosslett, 2017). These results revealed that labor availability for farming is low in other Asian countries also. Moreover, in Bhutan, majority $(54.1 \%)$ of the farm families fall under the low labour availability group, $39.4 \%$ is in medium labour availability category and only $6.6 \%$ is in high labour availability category. Majority of the respondents have only 1 - 2 farm labours for farming to support, even though it is the main source of livelihood of them (Yeshey and Bajgai, 2014). Not only that, majority of the farmers in US are male and 
more than half of the farmers are over 50 years of age and also most of the farmers in some states such as Northern state are not highly educated although they have good agricultural systems (William et al., 2009).

\section{Farmers'level of awareness about glyphosate}

Farmers' levels of awareness about glyphosate and the impacts of glyphosate and sources of getting knowledge were evaluated. The findings are presented in the Table 03.

According to the information of the Table 03, more than $50 \%(47+23 \%)$ of the farmers have a significant level of knowledge about glyphosate and the impact of glyphosate. While $26 \%$ of farmers had little knowledge, 4\% hadn't any knowledge about the impacts of glyphosate.
As people of the country have a general level of education they can understand main things happened in the society especially, things affecting them. When the situations of other countries are concerned, in Central Europe, comparatively high numbers of farmers $(23 \%)$ have stated that they did not use glyphosate in farming (Wiese et al., 2017). This indicates that they were well aware about the glyphosate and its harmful effects. Furthermore, in Bhutan, the effectiveness of glyphosate in controlling weeds has been rated as "highly effective" by majority $(67.5 \%)$, the other $32.5 \%$ of respondents has mentioned its efficacy as "moderately effective" (Yeshey and Bajgai, 2014). This indicates that they used glyphosate than other countries and they have a lower level of awareness about harmful effects of glyphosate.

Table 02: Socio-economic factors of the farmers $(n=100)$

\begin{tabular}{|c|c|c|}
\hline \multicolumn{2}{|c|}{ Socio-economic factor } & \multirow{2}{*}{$\frac{\text { Percentage }(\%)}{79}$} \\
\hline Gender & Male & \\
\hline verider & Female & 21 \\
\hline \multirow{5}{*}{ Age (years) } & $25-35$ & 02 \\
\hline & $36-45$ & 20 \\
\hline & $46-55$ & 36 \\
\hline & $56-65$ & 35 \\
\hline & $>65$ & 07 \\
\hline \multirow{3}{*}{ Marital status } & Married & 86 \\
\hline & Unmarried & 07 \\
\hline & Other & 07 \\
\hline \multirow{4}{*}{ Education } & No education & 03 \\
\hline & Primary education & 32 \\
\hline & Ordinary Level & 42 \\
\hline & Advance Level & 23 \\
\hline \multirow{3}{*}{ Family size } & $<3$ & 05 \\
\hline & $3-5$ & 71 \\
\hline & $>5$ & 24 \\
\hline \multirow{4}{*}{ Land size (Ac) } & $<1 / 4$ & 31 \\
\hline & $1 / 4-1 / 2$ & 36 \\
\hline & $1 / 2-1$ & 25 \\
\hline & $>1$ & 08 \\
\hline \multirow{4}{*}{ Monthly income (LKR) } & $<25,000$ & 31 \\
\hline & $25,000-50,000$ & 38 \\
\hline & $50,000-75,000$ & 25 \\
\hline & $>75,000$ & 06 \\
\hline
\end{tabular}


There were numbers of different sources of knowledge for the farmers in this area. Most common source is the agriculture instructor. All the farmers attend the seasonal meetings to gain information. Next one is agro chemical retail shops where herbicides are sold, followed by other farmers and advertisements. According to the data collected only $11 \%$ of farmers were having access to the internet to gain knowledge. It can be concluded that still there is a good public agricultural extension service in this area. Other than that, media is functioning well. However, the critical point is that, a significant level of agrochemical sellers are giving farming instructions for the farmers without having proper understanding. Another important thing is that, still the use of internet is at a lower level among the farmers in the country. Similarly, William et al. (2009) reported in their study the internet usage by farmers was less than $1 \%$. It revealed that the use of internet is at a lower level among the farmers in US. But their primary source of information was farm press publications. Further, they have reported that farmers with moderate or high levels of concern regarding glyphosate resistant weed management and prevention, most often they obtained information from universities or cooperative extension services (CES) compared to those with low levels of concern. Farmers with low or moderate levels of concern received their information from dealers or retailers rather than from universities. North Carolina farmers were more likely to obtain information from universities or CES than those in other states in US.

\section{Cost for herbicide and returns from paddy before and after the banning}

Majority of the farmers had spent less than Rs. 1000.00 for herbicides $(1.29 \%$ of the total cost of production) before banning of glyphosate. But after banning of it, majority of the farmers had to spend money from Rs. 1000.00 to Rs. 2500.00 (4.58\% of the total cost of production). Results of the paired T test are present in the Table 04.

Table 04 shows that $p$ values for pair 1 (the cost spent for herbicide after and before the banning of glyphosate) and pair 2 (cost of production after and before the banning of glyphosate) are less than 0.05 . So, they indicate that there are significant increases in cost spent for herbicide after banning glyphosate and also in cost of production after banning of glyphosate. Due to unavailability of glyphosate, as farmers apply various other herbicides time to time hoping to control weeds, cost spent for herbicide has increased. Thus cost of production has also increased compared to using glyphosate and this also effects on national economy.

Schmitz et al. (2012) also calculated the farmlevel effects of a ban of glyphosate and reported that gross margins would decrease in eastern Germany by $27 \%$, in northern Germany by $3 \%$ and in the north-western coastal area by $36 \%$. The total annual EU-welfare in case of a ban on glyphosate would be reduced by a minimum of US\$ 1.4 billion to a maximum of US\$ 4.2 billion. But in 2007 and 2008 the University of Arkansas has shown a reduction of rice yield by $80 \%$ from glyphosate, as well as glufosinate. Yeshey and Bajgai (2014) concluded that despite the difference in amount of money spent in purchasing glyphosate for an acre of land among the respondents, the use of glyphosate is still much cheaper by $65 \%$ than controlling weeds manually on the paddy terrace bunds in Bhutan and this could be the reason why the number of farmers using glyphosate is increasing over the years. Further they revealed that on average, a farmer spends Ngultrum (nu) 2005.00/Acre to clear weeds manually compared with nu. 702.00/ Acre using glyphosate. The increased number of the users over the years indicates the efficacy of the herbicide coupled by cheaper herbicide alternative. Hence, these findings confirm that farmers use glyphosate as a substitute for farm labour. 
Table 03: $\quad$ Farmers awareness on glyphosate and source of getting knowledge $(n=100)$

\begin{tabular}{lcc}
\hline & Factor & Percentage (\%) \\
\hline \multirow{4}{*}{ Awareness } & Not at all & 04 \\
& Poor level & 26 \\
& Moderate level & 47 \\
& High level & 23 \\
Source & Agriculture instructor & 53 \\
& Agro chemical Retail shops & 32 \\
& Other farmers & 26 \\
& Advertisements & 06 \\
\hline
\end{tabular}

Field survey, 2017

Table 04: $\quad$ Results of the Paired T test $(n=100)$

\begin{tabular}{llccc}
\hline \multicolumn{7}{c}{ paired t-test } \\
\hline \multicolumn{7}{c}{ t } & Correlation & Sig. (2-tailed) \\
\hline Pair 1 & Cost for herbicide (after \& before banning) & -3.078 & .541 & .002 \\
Pair 2 & Cost of production (after \& before banning) & -9.769 & .599 & .000 \\
\hline
\end{tabular}

\section{The farmers' attitude on glyphosate}

Farmers' attitude on glyphosate was assessed using 12 statements along with 5 point Likert scale as Strongly Agree, Agree, Neutral, Disagree, and Strongly Disagree. Except the statement No.02, values allocated for Likert scale points were, $5,4,3,2$, and 1 respectively. Since statement No 02 is a wrong statement, reverse allocation of marks was applied. Results are presented in the Table 05 .

According to the Table 05, there are very high mean values $(>4)$ for five statements. Those high mean values indicate that farmers are strongly agree with those five statements namely; "Glyphosate badly affects health", "I know about the glyphosate banning", "Glyphosate is the best solution for herbicide", "Glyphosate is the main reason for Chronic Kidney Disease (CKD)" and "Glyphosate banning causes many other troubles". While farmers agree with another 6 statements, they disagree with the second statement. Therefore, it can be concluded that most of the farmers have a better understanding about the advantages and disadvantages of glyphosate and banning of glyphosate. But it is needed to conduct more studies on farmers' attitude on glyphosate banning in Sri Lanka due to lack of available information. And also, it is very important to have an idea about farmers' attitude towards glyphosate rather than introducing an alternative, substitute or any other solution instead of using glyphosate.

Similar situations can be seen in other countries as well. For example, William et al. (2009) concluded that farmers in US with more than 200 ha were more concerned about glyphosate than those with, less than 200 ha. However, only $30 \%$ of farmers in US have thought that the usage of glyphosate was a serious issue. Few farmers thought field tillage and or using a non-glyphosate resistant crop, in rotation with glyphosate resistant crops would be an effective strategy. This indicates that majority are not well aware about the harmful effects of glyphosate. 
Table 05: $\quad$ Farmers' attitude on glyphosate $(n=100)$

\begin{tabular}{clccc}
\hline $\begin{array}{c}\text { Serial } \\
\text { No }\end{array}$ & \multicolumn{1}{c}{ Statement } & Mean & Std. Deviation & Remark \\
\hline 01 & Glyphosate is badly affected for health & 4.61 & 0.524 & Strongly Agree \\
02 & Glyphosate produces inside the country & 2.39 & 0.941 & Disagree \\
03 & I know about the glyphosate banning & 4.87 & 0.468 & Strongly Agree \\
04 & Today glyphosate is not available & 3.28 & 1.272 & Agree \\
05 & Glyphosate is easy to use & 3.85 & 1.129 & Agree \\
06 & Glyphosate is the best solution for herbicide & 4.26 & 1.115 & Strongly Agree \\
07 & Glyphosate causes for diseases & 3.23 & 0.892 & Agree \\
08 & Glyphosate is the main reason for chronic kidney disease & 4.77 & 0.605 & Strongly Agree \\
09 & Glyphosate banning will help to control the diseases & 3.36 & 1.028 & Agree \\
10 & Glyphosate banning is a good act & 3.96 & 1.042 & Agree \\
11 & Glyphosate banning causes for many other troubles & 4.28 & 0.687 & Strongly Agree \\
12 & Glyphosate banning helps farmers to move away from farming & 3.84 & 0.941 & Agree \\
\hline
\end{tabular}
Alternatives for glyphosate currently used by
the farmers

Alternatives for glyphosate used by the farmers were studied in detail. They are presented in the Table 06.

Alternatives that are used by farmers instead of glyphosate are shown in the Table 06. Most of the farmers $(56 \%)$ were using some other herbicides available in the market such as Gramoxone, MCPA 60, 2.4-DPA, Hedanol etc. Meanwhile $21 \%$ of the farmers were using a weeder to control weeds in their paddy fields. And also a more or less similar amount of farmers (19\%) were using self-innovative things to control weeds in their paddy lands such as Banana trunk drag throughout the field after filling the whole field with water (during land preparation time), use Aginamoto (Monosodium Glutamate) as a weedicide. Although farmers use these alternatives, they are not successful alternatives for the problem. Although manual weeding was the most common method in the past, at present, a very small number of farmers (04\%) are using manual weeding. Lack of family labour, unavailability of free time, high cost and dearth of hired labour etc have hindered manual weeding in paddy cultivation. Use of alternative methods to control weeds is less in Sri Lanka. A similar situation was reported from Germany where mechanical weeding and other herbicides are used as alternatives (Andert et al., 2015). But research conducted by Smith-Fiola in Central Maryland Research and Education Center has found that acetic acid herbicide products can give viable control for weeds and using higher (20\%) concentrations and application volume can improve weed control. Farmers in US believed that new herbicides would be introduced in time to control herbicide-resistant weeds and generally chose not to adopt alternative weed management tactics. The problem with this attitude is that no new herbicides with novel mechanisms of action are in the latter stages of development, and no herbicides with new modes of action have been released (William et al., 2009).

Table 06: Different alternatives used by the farmers $(n=100)$

\begin{tabular}{lc}
\hline \multicolumn{1}{c}{ Alternative } & Percentage (\%) \\
\hline Use of another herbicides & 56 \\
Use of a weeder & 21 \\
Use of self-innovative things & 19 \\
Use of manual weeding & 04 \\
\hline
\end{tabular}




\section{CONCLUSIONS AND}

\section{RECOMMENDATIONS}

\section{Conclusions}

According to the findings, majority of the paddy farmers are male and they are in middle age. They have a significant level of education. However, they have small size farm lands and a very small amount of monthly income.

Most of them are getting information on herbicide from the agriculture instructor of the division. Since it is a formal source, farmers can get correct information. But getting information from informal sources like agro chemical sellers, media etc is not so good. Very few farmers are using internet to get information about glyphosate.

When farmers' attitudes are concerned, majority has a very good understanding about advantages and disadvantages of glyphosate and banning of glyphosate. Farmers wish to gradually move away from synthetic herbicides and tend to use cultural practices because they have a good knowledge on impacts of glyphosate mainly the epidemic situation of CKD in Rajarata area. So, most of the farmers appreciate the decision of banning glyphosate in paddy cultivation although they fall into trouble with the banning. However, farmers are facing several problems at the moment due to sudden banning at once without giving a suitable alternative for glyphosate. With the banning of most widely used herbicide glyphosate farmers were moving to other herbicides such as MCPA 60, Gramoxone, 2, 4-DPA, Hedanol etc. But they are not effective like glyphosate. So they increase the amount of other herbicides used. The farmers are spending much on different herbicides, leaving the cost of production of paddy goes high due to increase in other herbicides and labor cost. Thus significant amount of paddy farmers are hoping to move away from paddy farming because of not having an effective herbicide to control weeds in the fields as weed clearance on the paddy fields is one of the key operations involved in paddy cultivation. So it is essential to introduce an active and cost effective herbicide for the paddy farmers for the sake of paddy cultivation in future.

\section{Recommendations}

According to the aboveresults, recommendations can be suggested for three parties as farmers, researchers and the government.

Farmers need to use cultural practices as much as possible, as chemical fertilizers cause negative impact for the environment and for the living beings. This information can be provided for the farmers through the agriculture instructors as farmers prefer to participate in the seasonal meetings. Other than that, the integrated weed management method can be practiced by farmers to manage the weeds effectively rather than using chemical herbicides. The problems of farmers' health should be an important concern for policy makers when looking at the economic efficiency of crops. Therefore, there is need to carry out studies in order to educate and advice farmers on a safe and harmless methodology.

Researches including agricultural officers need to find out better alternatives for glyphosate herbicide. They can do research on possible alternatives soon and check the feasibility at farmers' level. Farmers should be given proper training by the Agricultural Extension Officers on how to adopt Integrated Pest Management and the benefit of taking preventive measures on the farm so that they can remain healthy. Programs are needed to develop and transfer technology to farmers for economically sustainable and environmentally acceptable chemical management of weeds.

Furthermore, existing government should motivate farmers to use organic fertilizer, researches to carryout researches and find suitable alternatives. Applying a holistic approach, better solutions need to be found out immediately to save agriculture sector in the country. 


\section{Data availability statement}

The data sets generated during and/or analyzed during the current study are available from the corresponding author on reasonable request.

\section{ACKNOWLEDGMENT}

The authors wish to thank the paddy farmers for their valuable support throughout the research.

\section{REFERENCES}

Alam, M.M., Siwar, C. and Ekhwan, M.T. (2010). Socioeconomic Study of Climate Change: An Assessment of Agriculture and Livelihood Sustainability on Paddy Farming in Malaysia, LAP Lambert Academic Publishing: Saarbrucken, Germany. https:/www.researchgate.net/ publication/265785254_Socioeconomic_Study_of_Climate_Change_An_Assessment_of_ Agriculture_and_Livelihood_Sustainability_on_Paddy_Farming_in_Malaysia

Ananda, R. (2011). More Problems with Glyphosate: US Rice Growers Sound the Alarm. https:// www.globalresearch.ca/more-problems-with-glyphosate-us-rice...the.../24775. 02.04.2018.

Anon, (2009). A Look Back in History When Sri Lanka was known as The Granary of The East. http://rajaratarala.blogspot.com/2009/01/look-back-in-history-when-sri-lanka-was.html. 21.05.2018.

Benbrook, C. M. (2016). Trends in glyphosate herbicide use in the United States and globally. Environmental Sciences Europe. 28(1): 3. DOI: http://doi.org/10.1186/s12302016-0070-0.

Buffin, D. and Jewell, T. (2001). Health and Environmental Impacts of Glyphosate: The Implications of Increased Use of Glyphosate in Association with Genetically Modified Crops; The Pesticide Action Network UK. https://friendsoftheearth.uk/sites/default/files/downloads/ impacts_glyphosate.pdf. 10-21.

Census and Statistics Sri Lanka (2016). Census of population and Housing, Department of census and statistics, Sri Lanka. http://www.statistics.gov.lk. 08.04.2018.

District Secretariat- Rathnapura. (2016). Population Statistics. https://www.citypopulation.de/php/ srilanka-admin.php?adm1id=91. 13.04.2018.

Duke, S.O. and Powles, S. B. (2008). Glyphosate: a once-in-a-century herbicide. Pest Management Science. 64: 319-325. DOI: https://doi.org/10.1002/ps.1518

Ekanayaka, E.M.S.I., Weerakoon, S.R., Somaratne, S. and Weerasena, O.V.D.S.J. (2017). Developing herbicide resistant Sri-lankan rice (Oryza sativa L.) varieties: An Application of Self Organizing Map. Information Processing in Agriculture. 4:140-149. DOI: https://doi. org/10.1016/j.inpa.2017.02.002

EU settles dispute over major weed killer glyphosate. http://www.bbc.com/news/worldeurope-42135437. 27.11.2017.

Franz, J.E., Mao, M.K. and Sikorski, J.A. (1997). Behavior of Glyphosate in Soil, Hydrosoils, and Water - Methods for Glyphosate Analyses. In: Glyphosate: A Unique Global Herbicide. American Chemical Society. Washington, DC. 65-97. 
Giesy, J.P., Dobson, S. and Solomon, K.R. (2000). Ecotoxicological Risk Assessment for Roundup Herbicide. Reviews of Environmental Contamination and Toxicology 167: 35-120. DOI: https://doi.org/10.1007/978-1-4612-1156-3_2

Glusczak, L., Miron, D.S., Moraes, B.S., Simões, R.R., Schetinger, M.R.C., Morsch, V.M. and Loro, V.L., (2007). Acute Effects of Glyphosate Herbicide on Metabolic and Enzymatic Parameters of Silver Catfish (Rhamdia quelen). Comparative Biochemistry and Physiology - Part C. 146: 519-524. DOI: https://doi.org/10.1016/j.cbpc.2007.06.004

Hance, R.J. (1976). Adsorption of glyphosate by soils. Pesticide Science. 7: 363- 366. https://doi. org/10.1002/ps.2780070407

International Agency for Research on Cancer: World Health Organization. (2015). IARC Monographs Volume 112: evaluation of five organophosphate insecticides and herbicides. http://www.iarc.fr/en/media-centre/iarcnews/pdf/MonographVolume112.pdf.

Irangani, M, K, L. and Shiratake, Y. (2013). Indigenous Techniques Used In Rice Cultivation in Sri Lanka: An Analysis from an Agricultural History Perspective. Indian Journal of Traditional Knowledge. 12(4): 638-650. http://nopr.niscair.res.in/bitstream/123456789/22194/1/ IJTK\%2012\%284\%29\%20638-650.pdf

Jiraungkoorskul W., Upatham, E. S., Kruatrachue, M. Sahaphong, S., Vichasri-Grams, S. and Pokethitiyook, P. (2003). Biochemical and Histopathological Effects of Glyphosate Herbicide on Nile tilapia (Oreochromis niloticus), 18(4): 260-267. DOI: https://doi.org/10.1002/ tox. 10123

Lane, M., Nicola.L.,Saxena.J., Ramsier, C. and Dick, R.P. (2012). The Effect of Glyphosate on Soil Microbial Activity, Microbial Community Structure and Soil Potassium. Pedobiologia. 55(6): 335-342. DOI: https://doi.org/10.1016/j.pedobi.2012.08.001

Langiano, V. C. and Martinez, C. B. R. (2008). Toxicity and Effects of a Glyphosate-Based Herbicide on the Neotropical Fish (Prochilodus lineatus). Comparative Biochemistry and Physiology - Part C. 147(2): 222-231. DOI: https://doi.org/10.1016/j.cbpc.2007.09.009

Lanka Web. (2018). Glyphosate Ban Hits Sri Lankan Exports. http://www.lankaweb.com/news/ items/2018/02/25/glyphosate-ban-hits-sri-lankan-exports/. 08.04.2018.

Copping, L.G. (2014). Outlooks on Pest Management: Sri Lanka Bans the Sale and Use of Glyphosate 187. http://www.colombopage.com/archive_14A/Mar12_1394634963CH.php.

Ma, J., Lin, F., Wang, S. and Xu, L. (2003). Toxicity of 21 Herbicides to the Green Alga Scenedesmus quadricauda. Bulletin of Environmental Contamination and Toxicology. 71: 594-601. DOI: https://doi.org/10.1007/s00128-003-8521-X

Madsen, K.H. and Streibig, J.C. (2000). Simulating Weed Management in Glyphosate-Tolerant Crops: Greenhouse and Field Studies. Pesticide Management Science. 56: 340-344. DOI: https://doi.org/10.1002/(sici)1526-4998(200004)56:4\%3C340::aid-ps124\%3E3.0.co;2-8

Mathew, C.D. (2017).The Safety of Glyphosate. Daily News. 01.082017.

Monsanto.(2018).IARC Glyphosate Report Response. https://monsanto.com/company/media/ statements/glyphosate-report-response/. 06.05.2018. 
Mulleriyawa, R. (2015). Banning Agro-chemicals? Let's Make Rational Decisions Based on Sound Scientific Evidence and Risk-Benefit Assessment. http;//www.island.lk/index.php?page_ cat $=$ article-details\&page $=$ article-details...title. 19.07.2018.

Rice Research and Development Institute, Bathalagoda (RRDI). (2017). Rice Cultivation. https:// www.doa.gov.lk/rrdi/index.php/en/crop/42-crop-rice-cultivation. 18.06.2018.

Samarpitha, A., Vasudev, N. and Suhasini, K. (2016). Socio-economic Characteristics of Rice Farmers in the Combined State of Andhra Pradesh. Asian Journal of Agricultural Extension, Economics \& Sociology. 13(1): 1-9. DOI: https://doi.org/10.9734/ajaees/2016/28696

Samsel, A. and Seneff, S. (2015). Glyphosate, pathways to modern diseases III: Manganese, Neurological Diseases, and Associated Pathologies Surgical Neurology International 6(1): 45. DOI: https://doi.org/10.4103/2152-7806.153876

Sirinathsinghji, E. (2012). Pesticide Illnesses and GM Soybeans. Ban on Aerial Spraying Demanded in Argentina. ISIS Report. http://www.i-sis.org. uk/Pesticide illnesses_and_GM_soya.php. 01.04.2018.

Sprankle, P., Meggitt, W.F. and Penner, D., (1975a). Rapid Inactivation of Glyphosate in the Soil. Weed Science. 23: 224-228.

Statista, 2018. The statistical portal. https://www.statista.com > Chemicals \& Resources > Chemical Industry.

Szekacs, A. and Darvas, B. (2012). Forty Years with Glyphosate. In: Herbicides - Properties, Synthesis and Control of Weeds (Hasaneen, M. N. A. E.G., Ed.). InTech, Rijeka, Croatia. 247-284. DOI: https://doi.org/10.5772/32491

Cossslett, T.L. and Cosslett, P.D. (2017). Sustainable Development of Rice and Water Resources in Mainland Southeast Asia and Mekong River Basin. Environmental Sciences, Ashburn, Virginia, USA, 10: 1-14. DOI: https://doi.org/10.1007/978-981-10-5613-0_1

Waidyanatha, P. (2017). Glyphosate Ban must be Lifted. http://www.dailynews.lk/2017/12/22/ features/138023/glyphosate-ban-must-be-lifted. 21.05.2018.

Johnson, W.G., Owen, M.D.K., Kruger, G.R., Young, B.G., Shaw, D.R., Wilson, R.G., Wilcut, J.W., Jordan, D.L. and Weller, S.C. (2009). U.S. Farmer Awareness of Glyphosate-Resistant Weeds and Resistance Management Strategies. Weed Technology. 23(2): 308-312. DOI: https://doi.org/10.1614/wt-08-181.1

Yeshey, Y. and Bajgai. (2014). An Assessment Of Glyphosate Use and its Cost Effectiveness as a Substitute for Farm Labour on Paddy Terrace Bunds. Journal of Renewable Natural Resources. 10: 27-34. https://www.researchgate.net/profile/Yadunath_Bajgai/publication/277223323 An_assessment_of_glyphosate_use_and_its_cost_effectiveness_as_a_substitute_for_farm _ labour_on_paddy_terrace_bunds/links/5570125208aefcb861dd.b9e3.pdf 